\title{
THE FORMOL-GEL REACTION AND ERYTHROCYTE SEDIMENTATION RATE IN ACUTE RHEUMATISM
}

\author{
By C. A. GREEN, S. THOMSON, AND A. J. GLAZEBROOK
}

\section{INTRODUCTION}

GATÉ and Pappacostas (1920) observed that the addition of formaldehyde to Wassermann-positive sera resulted in the solidification of 85 per cent. of specimens, while approximately the same proportion of Wassermann-negative sera failed to react in this way. They suggested that this reaction was due to an abnormal distribution of serum proteins. Holborrow (1922) found that forty-five of sixty-four Wassermann-positive sera gave a positive formol-gel reaction, and also seventeen of eighty-nine Wassermann-negative sera. He concluded that the gelation was due to direct action of the formalin on the serum proteins, and from experimental work considered it probable that acid-protein produced a gel with formalin, while alkaliprotein had not this property. Napier (1921-22) and Spackman (1921) observed a similar phenomenon in kala-azar, but noted a difference in appearance between the gelation in that disease and in syphilis. In kala-azar the serum became opaque and very firm in consistence, as though inspissated, within a few minutes, whereas gelation was relatively delayed in syphilitic sera, taking up to twenty-four hours to appear, and the gel formed was soft and transparent.

As regards the correlation of the formol-gel test with other biological tests, Napier and Henderson (1931) first observed parallelism with the erythrocyte sedimentation test in kala-azar, but they considered the formol-gel test was inferior for diagnostic or prognostic purposes. Pfeffer (1925) stated that the formolgel test was positive in a proportion of cases of chronic rheumatism and of tuberculosis of the exudative type. Gibson (1938) applied the test, in parallel with the erythrocyte sedimentation rate, to a series of 100 cases of chronic rheumatism. Using plasma, he found that the formol-gel test was negative in 40 of 42 


\section{A. GREEN, S. THOMSON AND A. J. GLAZEBROOK 181}

cases with normal sedimentation rates, and positive in 33 of 34 cases with markedly increased sedimentation rates. Approximately half the cases showing a moderate increase in sedimentation rate were positive. $\mathrm{He}$ noted a very close parallelism between the two tests, and considered that it may be of use as an additional pathological criterion of activity in chronic rheumatism. Gibson emphasised that the formol-gel test was less sensitive than the sedimentation test in finding evidence of activity in early cases, and considered that it should be used as a supplementary, but not substitute test. On the other hand, Schultz and Rose (1939) expressed the opinion that, whereas in various febrile illnesses other than rheumatic fever a close parallelism was demonstrable between the erythrocyte sedimentation rate and the formol-gel reaction, unique results were obtained in rheumatic fever. Early in the course of illness negative formol-gel reactions were frequently associated with very rapid sedimentation rates, while after the development of active carditis positive gel reactions often appeared when the sedimentation rate was reverting to normal limits. They concluded that the formol-gel reaction was of value in determining the presence of active carditis in patients known to be suffering from rheumatic fever.

This paper records observations on both tests in a group of young male adults in the various phases of acute and subacute rheumatism.

\section{Methods}

Determination of Erythrocyte Sedimentation Rate.10 c.c. of venous blood was thoroughly shaken with $0.02 \mathrm{gm}$. neutral potassium oxalate in a screw-cap bottle. The Zeckwer and Goodell (1935) method was adopted in principle. Within three hours of the collection of the specimen a 5 c.c. centrifuge tube, graduated in 0.05 c.c., was filled to the 5 c.c. mark with oxalated blood. The volume of the sedimented red cells was noted after one hour at room temperature. This result was expressed as the percentage volume of red cells, the percentage sign being omitted-e.g., E.S.R. 60 indicates that the volume of red cells, after one hour, was 60 per cent. of the total volume of blood. It should be noted that any increase in this figure is interpreted as an approximation to the normal. This reading is, therefore, the reverse of the more usual method of expressing 
the sedimentation rate as the length of the cleared plasma column above the sedimented cells.

HatMATOCRIT VolUME.-The graduated tube containing 5 c.c. blood was centrifuged for fifteen minutes at 3,000 revolutions per minute, and the packed red-cell volume expressed as a percentage of the whole blood volume.

Formol-Ges Test.-The supernatant plasma in the centrifuge tube was then separated for the formol-gel test, the quantitative method suggested by Gibson (1938) being used. The only modification introduced was the reduction to half-volume of the various reagents, the relative proportions remaining the same, as follows:

$\begin{array}{lrccccccc} & \text { Tube : } & 1 & 2 & 3 & 4 & 5 & 6 & 7 \\ \text { Plasma } & \ldots & 0.5 & 0.45 & 0.4 & 0.35 & 0.3 & 0 \cdot 25 & 0.5 \\ \text { Saline } & \therefore & 0.0 & 0.05 & 0.1 & 0.15 & 0.2 & 0.25 & 0.0 \\ \text { 18\% formalin } & 0.04 & 0.04 & 0.04 & 0.04 & 0.04 & 0.04 & 0.0\end{array}$

The tubes were placed in a Wassermann rack supported at one end so that the long axis of the tubes was nearer the horizontal than the vertical plane. After eighteen hours at room temperature the sloped tubes were returned to the vertical position and the occurrence of solidification noted. The results were expressed as follows:

$$
\begin{aligned}
& \left.\begin{array}{l}
1+ \\
2+
\end{array}\right\} \text { Degrees of partial coagulation of undiluted plasma. } \\
& 3+\text { : Complete coagulation of undiluted plasma. } \\
& 4+\text { : Complete coagulation of plasma diluted } 0.9 \text { in } 1 \text {. } \\
& 5+\text { : Complete coagulation of plasma diluted } 0.8 \text { in } 1 \text {. } \\
& 6+\text { : Complete coagulation of plasma diluted } 0.7 \text { in } 1 \text {. } \\
& 7+\text { : Complete coagulation of plasma diluted } 0.6 \text { in } 1 \text {. } \\
& 8+\text { : Complete coagulation of plasma diluted } 0.5 \text { in } 1 \text {. }
\end{aligned}
$$

N.B.-The following contractions will be used in the text:

E.S.R.: Erythrocyte sedimentation rate.

H.V.: Hæmatocrit volume.

F.G.T.: Formol-gel test.

\section{Results}

Before attempting to correlate the E.S.R., H.V. and F.G.T. results, certain basic data were required. The majority of the subjects studied were aged sixteen to eighteen years, and it was considered desirable to ascertain the average or normal limits of these tests in health for this particular age-group and community. All patients were serially tested at the end of prolonged convalescence when about to be discharged as fit. The distribution 
of the E.S.R. results at this time is illustrated in Chart 1. Although the majority of the tests upon which this chart was constructed were obtained from rheumatic subjects, a few patients completely recovered from scarlatina and from tonsillitis were included. The series was therefore constituted as follows: 107 tests from 76 rheumatic patients, single tests from 7 cases of scarlatina and from 11 cases of post-tonsillitis patients. Chart 1 indicates that at the end of convalescence the E.S.R. was most frequently at the 95-96 level, the next largest groups being immediately adjacent to the latter. The average E.S.R.,

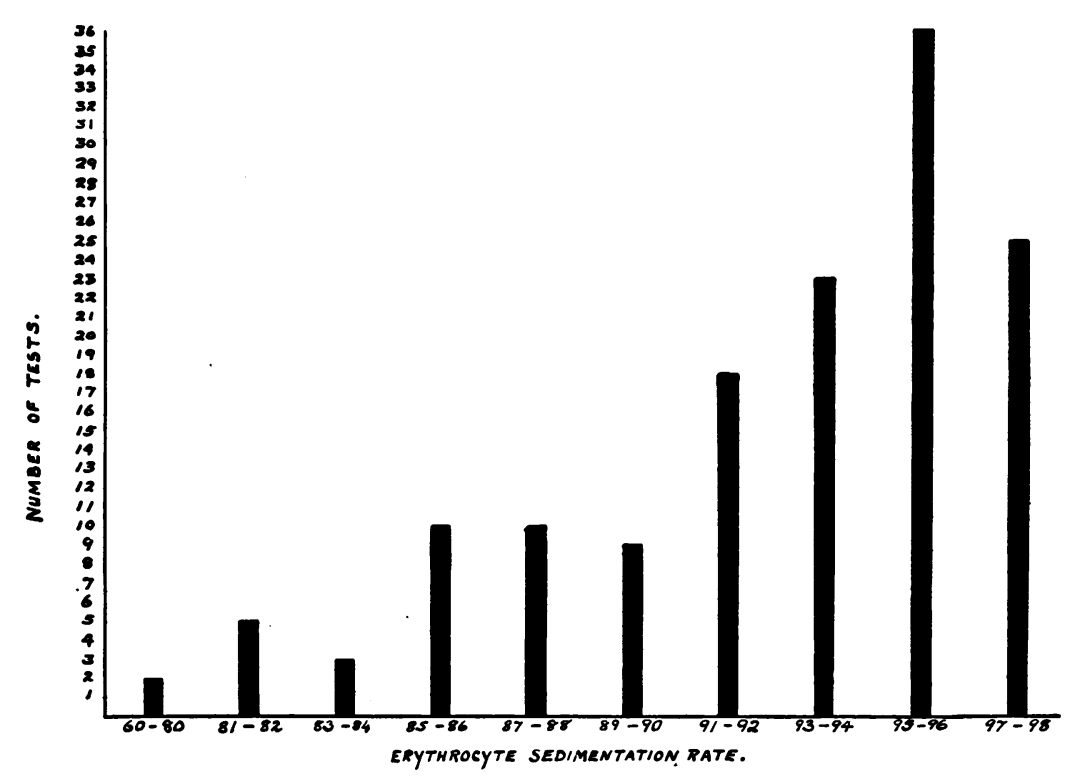

Chart 1.

determined by dividing the total of all E.S.R. results by the number of tests, was found to be $92 \cdot 4$. Table I. shows even more significantly the high E.S.R. of patients on discharge from hospital, 75.2 per cent. of specimens being over 90 and 99.2 per cent. over 80. For this reason it was concluded that, although an E.S.R. between 80 and 90 could be considered as possibly abnormal, an E.S.R. below 80 was almost certainly abnormal.

In the same way data on the H.V. of boys on discharge in health were sought. Chart 2 shows that the mean figure was most frequently at the 46-48 level, while the distribution of results 
on either side of this group fell in the expected manner. The average H.V., determined as above, was $47 \cdot 9$. Table II. shows that the H.V. of 81.4 per cent. of specimens was 45 or higher, and in every case was above 40. All hæmatocrit volumes lower than 40 were therefore considered to be almost certainly abnormal, and those between 40 and 45 as possibly, but not commonly, in the same category.

Erythrocyte Sedimentation Rates and Formol-Gel Test in Rheumatism.-Both tests were applied in parallel in a series of 102 cases of rheumatism in the acute, subacute and

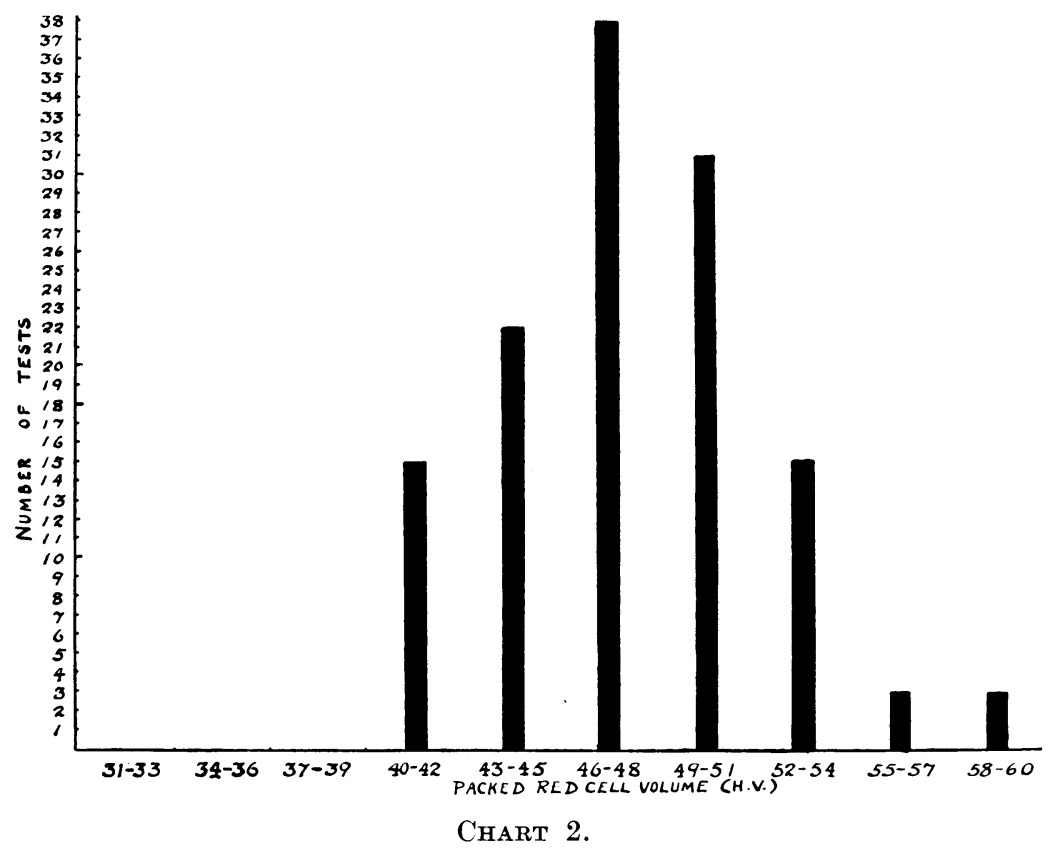

convalescent phases. Of this group, 96 cases were boys, aged sixteen to nineteen years, who had been living for some months under similar environmental conditions. The combined results are grouped in Table III. Only $2 \cdot 6$ per cent. of 266 specimens with an E.S.R. over 80 gave a positive F.G.T., as compared with $97 \cdot 1$ per cent. of specimens with an E.S.R. lower than 60 . Approximately half the cases with an E.S.R. between these limits were positive. In Table IV. the correlation is indicated in greater detail. Only one positive F.G.T. was found in a series of 173 tests when the E.S.R. was above 90, whereas every E.S.R. 
below 50 was accompanied by a positive F.G.T. The intervening groups were proportionately related. A further point of interest in the table is that 70.8 per cent. of positive F.G. tests were recorded in 161 specimens with an E.S.R. below 80, as compared with $2 \cdot 6$ per cent. of 266 specimens in the group above 80 . On grouping the positive F.G.T. results at various levels of the E.S.R., as in Table V., there was demonstrated a progressive increase in the mean F.G.T. result as the E.S.R. level fell.

Hamatocrit Volume and Formol-Gel Test in RheUMATISM.-Following the method of comparison used by Gibson (1938), Table VI. shows the mean E.S.R. and mean H.V. of specimens grouped according to the results of the F.G.T. A reduction in intensity of the positive F.G. reaction was accompanied by progressive increase of the mean E.S.R. and mean H.V. The only exception to be noted in the table was the slightly higher mean H.V. of 40.3 in the $5+$ F.G. group as compared with $39 \cdot 2$ in the $4+$ F.G. group. Otherwise the correlation was complete. The negative F.G. group included specimens taken in early as well as in late stages of illness, and hence the mean S.R. and H.V. values of 86.6 and $44 \cdot 1$ respectively were lower than those determined at the end of convalescence in the preliminary group, in which the formolgel test was invariably negative.

Table VII. shows the percentage of positive F.G. tests at various levels of the H.V. It will be seen that the F.G.T. was positive in 48 , or 92.3 per cent., of 52 specimens with an H.V. lower than 40 , as compared with 2 , or 1.8 per cent., of 113 specimens with an H.V. above 50. Between these two levels, 26.6 per cent. of specimens reacted positively to the F.G.T.

\section{Failure in Agreement of Test Results}

The instances in which the E.S.R. and F.G.T. failed to give comparable results may now be considered.

E.S.R. WITHIN Normal Limits, F.G.T. Positive.-Taking 80 as the lower limit of normality for the E.S.R. test, 7 specimens were found to give a normal E.S.R., but positive F.G.T.

CASE 1

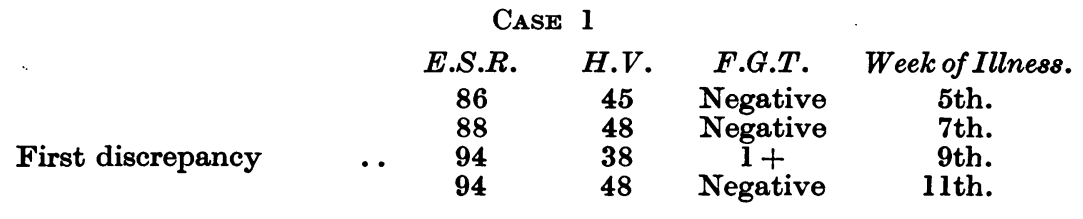


This was the only case in which an E.S.R. greater than 90 was accompanied by a positive F.G.T. As seen in the serial record, the F.G.T. was a weak positive.

CASE 2

$\begin{array}{cccccc} & & \text { E.S.R. } & \text { H.V. } & \text { F.G.T. } & \text { Week of Illness. } \\ \text { Second discrepancy } & & 63 & \mathbf{4 5} & 2+ & \text { 8th. } \\ & & \mathbf{8 2} & \mathbf{5 0} & \text { 1 } & \text { 10th. } \\ & & \mathbf{9 2} & \mathbf{4 4} & \text { Negative } & \text { 12th. } \\ & & \mathbf{8 2} & \mathbf{5 1} & \text { Negative } & \text { 13th. }\end{array}$

From the eighth to the tenth week of illness there was a marked improvement in the E.S.R., but the F.G.T. was still weakly positive during this transition period.

CASE 3

E.S.R. H.V. F.G.T. Week of Illness.

$\begin{array}{llllll} & & 70 & 40 & 3+ & \text { 4th. } \\ \text { Third discrepancy } & \ldots & 80 & 44 & 2+ & \text { 6th. } \\ \text { Fourth discrepancy } & \ldots & 82 & \mathbf{4 4} & \text { 1+ } & \text { 9th. } \\ & & \mathbf{8 2} & \mathbf{4 0} & \text { Negative } & \text { 14th. }\end{array}$

Again, during a transition period in the patient's progress the E.S.R., while in the limits of normality, was accompanied by a positive F.G.T.

\section{CASE 4}

E.S.R. H.V. F.G.T. Week of Il!ness.

Fifth discrepancy $\quad$.. 82

$\begin{array}{llll}79 & 45 & 3+ & 3 r d\end{array}$

$\begin{array}{llllll}\text { Sixth discrepancy } & \ldots & \mathbf{8 0} & \mathbf{4 8} & 3+ & \text { 4th. } \\ & & 90 & 49 & \text { 3 } & \text { 6th. }\end{array}$

$90 \quad 49$ Negative . 8th.

Disagreement occurred in the fourth and sixth weeks of a relapse when joint pains and pyrexia were still present. The result of the F.G.T. was a more reliable indication of the clinical condition than the E.S.R.

\section{CASE 5}

E.S.R. H.V. F.G.T. Week of Illness.

$\begin{array}{llcccc} & & 91 & 50 & \text { Negative } & \text { 1st. } \\ \text { Seventh discrepancy } & \ldots & \mathbf{8 6} & \mathbf{3 6} & \mathbf{3}+ & \text { 2nd. }\end{array}$

In this early case stiffness and pain on movement of the leg were the only symptoms present.

In this group, therefore, there was no serious degree of disparity between the results of the two tests.

E.S.R. Below Normal Limits, F.G.T. Negative.-In 47 specimens with a negative F.G.T. the E.S.R. was below 80 . 
As seen in Table IV., 31 of these were in the group with an E.S.R. between 79 and 70 , and could be considered as border-line cases similar to those above. The remaining 14 discrepancies of greater degree were as follows:

CASE 6

$\begin{array}{cccccc} & & & & & \\ & & \text { S.R. } & \text { H.V. } & \text { F.G.T. } & \text { Week of Illness. } \\ & & 94 & 50 & \text { Negative } & \text { 12th. } \\ \text { First discrepancy } & & 90 & 46 & \text { Negative } & \text { 14th. } \\ & \ldots & 58 & 42 & \text { Negative } & \text { 18th. } \\ & & \mathbf{7 5} & 44 & \text { Negative } & \text { 20th. }\end{array}$

On returning from four weeks' sick-leave, eighteen weeks after the onset of illness, no clinical abnormality was detected to account for the abnormal E.S.R.

\section{CASE 7}

$\begin{array}{lccccc} & & \text { E.S.R. } & \text { H.V. } & \text { F.G.T. } & \text { Week of Illness. } \\ \text { Second discrepancy } & \ldots & 50 & 42 & \text { Negative } & \text { lst. } \\ & & 65 & 42 & \text { 3+ } & \text { 2nd. }\end{array}$

In this early case there was a definite lag in the appearance of the positive formol-gel reaction.

\section{CASE 8}

$\begin{array}{cccccc} & & E . S . R . & H . V . & \text { F.G.T. } & \text { Week of Illness. } \\ \text { Third discrepancy } & \ldots & 66 & 45 & \text { Negative } & \text { 2nd. } \\ & & 88 & 49 & \text { Negative } & \text { 4th. } \\ & & 90 & 47 & \text { Negative } & \text { 5th. } \\ & & 92 & 48 & \text { Negative } & \text { 6th. } \\ & & 64 & 50 & \text { Negative } & \text { 8th. } \\ & & 46 & 37 & \text { 1+ } & \text { 10th. } \\ & & & \text { 5 } & \text { 12th. } \\ & & 42 & \text { Negative } & \text { 15th. }\end{array}$

Examined for the first time in the second week of illness, the E.S.R. was definitely abnormal, while the F.G.T. was still negative. The ensuing seven results were in agreement.

\begin{tabular}{|c|c|c|c|c|c|}
\hline \multicolumn{6}{|c|}{ Case 9} \\
\hline Fourth discrepancy & . & $\begin{array}{c}\boldsymbol{E} . S . R . \\
69 \\
72 \\
56 \\
58 \\
60 \\
66 \\
52 \\
62\end{array}$ & $\begin{array}{c}H . V . \\
\mathbf{5 0} \\
\mathbf{7 0} \\
\mathbf{7 9} \\
\mathbf{6 2} \\
\mathbf{6 4} \\
\mathbf{6 2} \\
\mathbf{6 2} \\
\mathbf{7 2}\end{array}$ & $\begin{array}{c}F . G . T . \\
\text { Negative } \\
\text { 5+ } \\
\mathbf{8}+ \\
\mathbf{4}+ \\
\mathbf{5}+ \\
\mathbf{5}+ \\
\mathbf{5}+ \\
\mathbf{1}+\end{array}$ & $\begin{array}{c}\text { Week of Illness. } \\
\text { 1st. } \\
\text { 3rd. } \\
\text { 4th. } \\
\text { 5th. } \\
\text { 6th. } \\
\text { 7th. } \\
\text { 9th. } \\
\text { 11th. }\end{array}$ \\
\hline
\end{tabular}


In this case, also, there was a definite lag in the appearance of the positive F.G.T., but thereafter the two tests approximated closely.

\begin{tabular}{|c|c|c|c|c|c|}
\hline \multicolumn{6}{|c|}{ Case 10} \\
\hline & & E.S.R. & H.V. & $F \cdot G . T$. & Week of Illness. \\
\hline Fifth discrepancy & $\cdots$ & $\begin{array}{r}62 \\
68 \\
\cdot 64 \\
60 \\
55 \\
64\end{array}$ & $\begin{array}{l}42 \\
42 \\
45 \\
44 \\
42 \\
45\end{array}$ & $\begin{array}{c}5+ \\
6+ \\
\text { Negative } \\
4+ \\
4+ \\
2+\end{array}$ & $\begin{array}{l}\text { 2nd. } \\
\text { 3rd. } \\
\text { 6th. } \\
\text { 7th. } \\
\text { 9th. } \\
\text { 1lth. }\end{array}$ \\
\hline
\end{tabular}

After being strongly positive in the second and third weeks the F.G.T. was negative in the sixth week, while the E.S.R. remained at the same low level as in the previous weeks. In the subsequent tests the results were in agreement. No explanation for this discrepancy was discovered.

Case 11

\begin{tabular}{|c|c|c|c|c|c|}
\hline & & E.S.R. & H.V. & $F \cdot G . T$ & Week of Illness \\
\hline & & $\begin{array}{l}96 \\
85 \\
72\end{array}$ & $\begin{array}{l}\mathbf{5 0} \\
\mathbf{4 4} \\
\mathbf{4 5}\end{array}$ & $\begin{array}{c}\text { Negative } \\
\text { Negative } \\
\mathbf{3}+\end{array}$ & $\begin{array}{l}\text { 2nd. } \\
\text { 3rd. }\end{array}$ \\
\hline Sixth discrepancy & . & 65 & 42 & Negative & 5th. \\
\hline Seventh discrepancy & .. & 62 & 41 & Negative & 7th. \\
\hline & & 73 & 46 & Negative & 9th. \\
\hline & & 90 & 45 & Negative & 1lth. \\
\hline
\end{tabular}

In the fourth week of illness a fall in the S.R. was accompanied by complete gelation of the plasma. In the following four weeks a still further fall in the E.S.R. occurred, but the F.G.T. had returned to normal limits.

\begin{tabular}{|c|c|c|c|c|c|}
\hline \multicolumn{6}{|c|}{ Case 12} \\
\hline & & E.S.R. & $H . V$. & F.G.T. & Week of Illness. \\
\hline $\begin{array}{l}\text { Eighth discrepancy } \\
\text { Ninth discrepancy }\end{array}$ & $\ddot{m}$ & $\begin{array}{l}\mathbf{7 6} \\
\mathbf{7 4} \\
\mathbf{5 0} \\
\mathbf{6 5} \\
\mathbf{6 0} \\
\mathbf{6 2} \\
\mathbf{7 5} \\
\mathbf{7 7}\end{array}$ & $\begin{array}{l}48 \\
43 \\
40 \\
40 \\
40 \\
40 \\
40 \\
40\end{array}$ & $\begin{array}{c}3+ \\
3+ \\
3+ \\
4+ \\
\text { Negative } \\
\text { Negative } \\
\text { Negative } \\
\text { Negative }\end{array}$ & $\begin{array}{l}\text { 2nd. } \\
\text { 4th. } \\
\text { 5th. } \\
6 \text { th. } \\
\text { 7th. } \\
\text { 9th. } \\
\text { 11th. } \\
\text { 13th. }\end{array}$ \\
\hline
\end{tabular}

In this case the F.G.T. had returned to the negative phase at least four weeks before improvement in the E.S.R. began. 


\section{CASE 13}

$\begin{array}{cccccc} & & E . S . R . & H . V . & \text { F.G.T. } & \text { Week of Illness. } \\ \text { Tenth discrepancy } & \ldots & \mathbf{6 7} & \mathbf{4 2} & \text { Negative } & \text { 3rd. } \\ & & \mathbf{7 7} & \mathbf{4 6} & \text { Negative } & \text { 5th. } \\ & & \mathbf{8 5} & \mathbf{5 0} & \text { Negative } & \text { 6th. } \\ & & \mathbf{9 6} & \mathbf{4 5} & \text { Negative } & \text { 7th. } \\ & & \mathbf{9 6} & \mathbf{5 0} & \text { Negative } & \text { 9th. }\end{array}$

This patient was examined for the first time in the third week of illness, when no acute symptoms were present. The E.S.R. was then abnormal, but the F.G.T. negative.

\section{Case 14}

E.S.R. H.V. F.G.T. Week of Illness.

$\begin{array}{llllll} & & 50 & 40 & 5+ & \text { 1st. } \\ & & \mathbf{4 6} & \mathbf{3 7} & \mathbf{6}+ & \text { 2nd. } \\ & & \mathbf{5 7} & \mathbf{3 5} & \mathbf{6}+ & \text { 3rd. } \\ \text { Eleventh discrepancy } & & \mathbf{4 6} & \mathbf{3 8} & \mathbf{4}+ & \text { 4th. } \\ & & \mathbf{6 0} & \mathbf{5 0} & \text { Negative } & \text { 5th. } \\ & & \mathbf{4 5} & \mathbf{3 6} & \mathbf{4}+ & \text { 6th. } \\ & & \mathbf{5 1} & \mathbf{4 2} & \text { 3+ } & \text { 8th. } \\ & & \mathbf{8 2} & \mathbf{4 2} & \text { Negative } & \text { 10th. }\end{array}$

This disagreement in the fifth week was due to the partial clotting of the blood specimen in the collection bottle. Complete agreement was found at all other times.

CASE 15

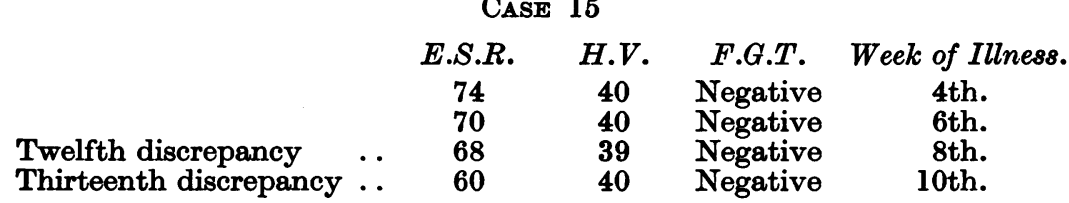

Despite the fall in the E.S.R., the F.G.T. remained negative in the eighth and tenth weeks.

Case 16

$\begin{array}{ccccc} & \text { E.S.R. } & \text { H.V. } & \text { F.G.T. } & \text { Week of Illness. } \\ & 95 & 44 & \text { Negative } & \text { 2nd. } \\ \text { Fourteenth discrepancy .. } & 60 & 45 & \text { Negative } & \text { 3rd. } \\ & 79 & 40 & 2+ & \text { 4th. }\end{array}$

In this last series of 14 discrepancies, the first 2 were the only specimens out of 75 with an E.S.R. below 60 which gave a negative F.G.T. The remaining examples were mainly borderline cases occurring at some transition period in the course of illness. These detailed examples otherwise serve to illustrate 
the correlation which can be expected between these two tests during the course of the infection.

Effect of Delay in Sedimentation Rate and FormolGeL TeST.-It is well recognised that there must be the minimum delay in setting up blood for the E.S.R. after the sample has been taken. This may introduce practical difficulties in obtaining results under standardised conditions, particularly if the laboratory be at some distance from the clinical material. For interest, preliminary investigations were made on the relative effect of delay on the E.S.R. and F.G.T. results. In 105 consecutive specimens both tests were carried out within three hours of collection, as in the routine method described previously. The E.S.R. and F.G. tests were then repeated twelve and twentyfour hours respectively, after the collection of blood. As shown in Table VIII., the sedimentation rate was markedly affected by delay, there being an increase in the twelve-hour E.S.R. in $77 \cdot 1$ per cent. of specimens. In 22 instances an E.S.R. below 80 at three hours was above that level after twelve hours, the increase sometimes being very marked-e.g., 62 to 89,65 to 93 . The formol-gel reaction was found to be much more stable, as Table IX. indicates. Although the period of delay was twice that introduced in the case of the E.S.R., there was no change in the twenty-four-hour F.G.T. result in 80.9 per cent. of specimens. Such variation as did occur was always slight, and never greater than $1+$. Only one specimen, initially negative, developed a weak $1+$ positive F.G.T. on repetition, and all positive results were confirmed by the second test.

\section{Discussion}

It is of great importance that any method of determining the activity of rheumatic infection should be fully investigated, even though the results of the test be non-specific in nature. This investigation supports the conclusions of Gibson (1938) that the formol-gel test is of value in supplementing the erythrocyte sedimentation test. The correlation in results corresponded very closely to those noted by Gibson, and outstanding discrepancies were rarely encountered. This finding is not in accord with the observations of Schultz and Rose (1939). In Table X. the two series of results are contrasted. It will be seen that Schultz and Rose noted 36.1 per cent. of positive formol-gel 
tests in specimens with markedly abnormal erythrocyte sedimentation rates-i.e., $100+$ (Schultz)-as compared with 97.6 per cent. in the present series. On the other hand, Schultz and Rose found that 18.5 per cent. of specimens with an erythrocyte sedimentation rate of 20 or less (Schultz) gave a positive formol-gel test, as compared with only 2.4 per cent. in the present series. A possible explanation for these divergent results was the greater frequency of delayed but persistent formol-gel reactions in the series recorded by Schultz and Rose. In the present investigation it was found that, in general, a change from a normal to an abnormal result in one test was synchronous with a similar change in the other. As compared with the sedimentation rate, there may be delay both in the appearance and disappearance of a positive gel reaction, as noted by Schultz and Rose (1939), but the positive gel reaction may precede the appearance of the initial abnormal result in the sedimentation rate.

In its quantitative form the formol-gel test furnished useful information regarding the progress of the individual case. Its utility becomes even greater if there is any possibility of delay in the examination of specimens. The preliminary work has shown that such delay, even up to thirty-six hours after the collection of blood, had little or no effect on the formol-gel test, whereas any delay beyond three hours or less may completely invalidate the results of the erythrocyte sedimentation rate.

\section{Conclusions}

1. The average erythrocyte sedimentation rate, as determined by the method of Zeckwer and Goodell (1935), and expressed as the percentage red-cell volume, in a group of male rheumatic convalescents aged sixteen to nineteen years was $94 \cdot 4$, and the average hæmatocrit volume 47.9. The formol-gel test was invariably negative.

2. In 99.2 per cent. of cases, on discharge from hospital the erythrocyte sedimentation rate was over 80 , and in 81.4 per cent. of cases the hæmatocrit volume was 45 or over.

3. 464 results of erythrocyte sedimentation rate and formolgel tests on blood specimens from 102 cases of acute rheumatism are compared. Positive formol-gel reactions occurred in $97 \cdot 1$ per cent. of specimens with an erythrocyte sedimentation rate 
below 60 , as compared with $2 \cdot 6$ per cent. in specimens with rates above 80 .

4. In $92 \cdot 3$ per cent. of 54 specimens with hæmatocrit volumes less than 40 gave a positive formol-gel reaction.

5. The formol-gel reaction was much less affected by delay than was the erythrocyte sedimentation test.

Table I.-Erythrocyte Sedimentation Rates of Male AdolesCents at End of Prolonged Convalescent Period after Acute RHEUMATISM

\begin{tabular}{|c|c|c|c|c|c|c|}
\hline \multicolumn{5}{|c|}{$\begin{array}{c}\text { Erythrocyte } \\
\text { Sedimentation Rate. }\end{array}$} & $\begin{array}{c}\begin{array}{c}\text { Number of } \\
\text { Tests. }\end{array} \\
56\end{array}$ & $\begin{array}{c}\begin{array}{c}\text { Percentage of } \\
\text { ALL Results. }\end{array} \\
44 \cdot 0\end{array}$ \\
\hline $\begin{array}{l}95 \text { or } \\
90 \quad, \\
85 \quad ", \\
80 \quad ", \\
75 \quad,\end{array}$ & $\begin{array}{l}\ldots \\
\cdots \\
\cdots \\
\cdots\end{array}$ & $\begin{array}{l}\cdots \\
\cdots \\
\cdots \\
\cdots\end{array}$ & $\begin{array}{l}\cdots \\
\cdots \\
\cdots \\
\cdots\end{array}$ & $\begin{array}{l}\cdots \\
\cdots \\
\cdots \\
\cdots\end{array}$ & $\begin{array}{r}56 \\
94 \\
116 \\
124 \\
125\end{array}$ & $\begin{array}{r}44 \cdot 0 \\
75 \cdot 2 \\
92 \cdot 8 \\
99 \cdot 2 \\
100 \cdot 0\end{array}$ \\
\hline
\end{tabular}

Table II.-To show the Hamatocrit Volume of Young Male Subjects (95) at End of Prolonged Convalescence after Acute RHEUMATISM

\begin{tabular}{|c|c|c|c|c|c|}
\hline \multicolumn{4}{|c|}{ Hoematocrit Volume. } & \multirow{2}{*}{$\begin{array}{c}\begin{array}{c}\text { Number of } \\
\text { Tests. }\end{array} \\
5 \\
46 \\
101 \\
124\end{array}$} & \multirow{2}{*}{$\begin{array}{c}\text { Percentage of } \\
\text { Tests. } \\
4 \cdot 0 \\
37 \cdot 1 \\
81 \cdot 4 \\
100 \cdot 0\end{array}$} \\
\hline $\begin{array}{l}55 \text { and over } \\
50 \quad, \\
45 \\
40\end{array}$ & $\begin{array}{l}\cdots \\
\cdots \\
\cdots\end{array}$ & $\begin{array}{l}\cdots \\
\cdots \\
\cdots\end{array}$ & $\begin{array}{l}\cdots \\
\cdots \\
\cdots\end{array}$ & & \\
\hline
\end{tabular}

Table III.-To show the Percentage of Positive Formol-Gel Reactions in Blood Specimens from Rheumatic SubJects with High, Low aNd INTERMEdiate ERYthrocyte SEDimentation RATES

\begin{tabular}{|c|c|c|c|c|c|c|}
\hline \multirow{2}{*}{\multicolumn{2}{|c|}{$\begin{array}{c}\text { Erythrocyte } \\
\text { Sedimentation } \\
\text { Rate. }\end{array}$}} & \multirow{2}{*}{$\begin{array}{l}\text { Number } \\
\text { of Tests. }\end{array}$} & \multicolumn{4}{|c|}{ Positive Formol-Gel. } \\
\hline & & & $\begin{array}{c}1+\text { and } \\
2+.\end{array}$ & $\begin{array}{c}3+\text { and } \\
\text { over } 3+\text {. }\end{array}$ & Total. & Percentage. \\
\hline $\begin{array}{r}100-80 \\
79-60 \\
59-30\end{array}$ & $\begin{array}{l}\ldots \\
\cdots \\
\cdots\end{array}$ & $\begin{array}{r}266 \\
91 \\
70\end{array}$ & $\begin{array}{r}4 \\
15 \\
6\end{array}$ & $\begin{array}{r}3 \\
31 \\
62\end{array}$ & $\begin{array}{r}7 \\
46 \\
68\end{array}$ & $\begin{array}{r}2 \cdot 6 \\
50 \cdot 6 \\
97 \cdot 1\end{array}$ \\
\hline \multicolumn{2}{|c|}{ Total .. } & 427 & 25 & 96 & 121 & $28 \cdot 3$ \\
\hline
\end{tabular}


Table IV.-To show the Correlation between the ERythrocyte Sedimentation Rate and Formol-Gel Reaction in Rheumatic SUBJECTS

\begin{tabular}{|c|c|c|c|c|c|c|}
\hline \multirow{2}{*}{\multicolumn{4}{|c|}{$\begin{array}{c}\text { Erythrocyte } \\
\text { Sedimentation Rate. }\end{array}$}} & \multirow{2}{*}{$\begin{array}{c}\begin{array}{c}\text { Number of } \\
\text { Tests. }\end{array} \\
173\end{array}$} & \multicolumn{2}{|c|}{ Positive Formol-Gel. } \\
\hline & & & & & \multirow{2}{*}{$\begin{array}{c}\text { Number. } \\
1 \\
6 \\
18 \\
28 \\
40 \\
27 \\
1\end{array}$} & Percentage. \\
\hline $\begin{array}{r}100-90 \\
89-80 \\
79-70 \\
69-60 \\
59-50 \\
49-40 \\
39-30\end{array}$ & $\begin{array}{l}\ldots \\
\cdots \\
\cdots \\
\cdots \\
\cdots\end{array}$ & $\begin{array}{l}\ldots \\
\cdots \\
\cdots \\
\cdots \\
\cdots\end{array}$ & $\begin{array}{l}\cdots \\
\cdots \\
\cdots \\
\cdots\end{array}$ & $\begin{array}{r}173 \\
93 \\
51 \\
40 \\
42 \\
27 \\
1\end{array}$ & & $\left.\begin{array}{r}0 \cdot 6 \\
6 \cdot 5\end{array}\right\} 2 \cdot 6$ \\
\hline
\end{tabular}

Table V.-To show the Mean Formol-Ger Reading of Rheumatic Plasma grouped according to the Level of the ERythroCYTE Sedimentation Rate

\begin{tabular}{|c|c|c|c|c|c|c|}
\hline \multicolumn{5}{|c|}{$\begin{array}{c}\text { Erythrocyte } \\
\text { Sedimentation Rate. }\end{array}$} & $\begin{array}{c}\text { Number of Posi- } \\
\text { tive Formol-Gel } \\
\text { Reactions. }\end{array}$ & $\begin{array}{c}\begin{array}{c}\text { Mean Formol } \\
\text { Gel Result. }\end{array} \\
1.0\end{array}$ \\
\hline $\begin{array}{r}100-90 \\
89-80 \\
79-70 \\
69-60 \\
59-50 \\
49-40 \\
39-30\end{array}$ & $\begin{array}{l}\ldots \\
\therefore \\
\therefore \\
\therefore\end{array}$ & $\begin{array}{l}\cdots \\
\cdots \\
\cdots \\
\cdots \\
\cdots\end{array}$ & $\begin{array}{l}\cdots \\
\cdots \\
\cdots \\
\cdots \\
\cdots\end{array}$ & $\begin{array}{l}\ldots \\
\cdots \\
\cdots \\
\cdots \\
\ldots\end{array}$ & $\begin{array}{r}1 \\
6 \\
18 \\
28 \\
40 \\
27 \\
1\end{array}$ & $\begin{array}{l}\mathbf{1} \cdot 0 \\
\mathbf{2} \cdot \mathbf{1} \\
\mathbf{3} \cdot 0 \\
\mathbf{3} \cdot \mathbf{4} \\
\mathbf{4} \cdot \mathbf{2} \\
\mathbf{5 \cdot 2} \\
\mathbf{8} \cdot \mathbf{0}\end{array}$ \\
\hline
\end{tabular}

Table VI.-To show the Mean Erythrocyte Sedimentation Rate and Mean Hamatocrit Volume of Blood Specimens From Rheumatic SUbJects Grouped according to the Result of THE FORMOL-GeL TeST

\begin{tabular}{|c|c|c|c|c|c|}
\hline \multicolumn{4}{|c|}{ Formol.Gel Test. } & \multirow{2}{*}{$\begin{array}{c}\text { Mean } \\
\text { E.S.R. }\end{array}$} & \multirow{2}{*}{$\begin{array}{l}\text { Mean } \\
H . V .\end{array}$} \\
\hline & Number. & & Result. & & \\
\hline $\begin{aligned} 9 & \cdots \\
14 & \cdots \\
25 & \cdots \\
23 & \cdots \\
30 & \cdots \\
28 & \cdots \\
314 & \cdots\end{aligned}$ & $\begin{array}{l}\ldots \\
\ldots \\
\ldots \\
\cdots \\
\ldots\end{array}$ & $\begin{array}{l}\cdots \\
\cdots \\
\cdots \\
\cdots \\
\cdots\end{array}$ & $\begin{array}{c}7+\text { or more } \\
6+ \\
5+ \\
4+ \\
3+ \\
2+\text { and } 1+ \\
\text { Negative }\end{array}$ & $\begin{array}{l}46 \cdot 3 \\
51 \cdot 2 \\
53 \cdot 8 \\
58 \cdot 0 \\
66 \cdot 6 \\
67 \cdot 9 \\
86 \cdot 6\end{array}$ & $\begin{array}{l}38 \cdot 5 \\
38 \cdot 6 \\
40 \cdot 3 \\
39 \cdot 2 \\
42 \cdot 4 \\
42 \cdot 7 \\
44 \cdot 1\end{array}$ \\
\hline
\end{tabular}


Table VII.-To show the Percentage of Positive Formol-Gel Reactions in Blood Specimens from Rheumatic SubJects GROUPED ACCORDING TO THE HAMATOCRIT VOLUME

\begin{tabular}{|c|c|c|c|c|c|c|}
\hline \multirow{2}{*}{\multicolumn{2}{|c|}{ Hoematocrit }} & \multirow{2}{*}{\multicolumn{2}{|c|}{ Volume. }} & \multirow{2}{*}{$\begin{array}{l}\text { Number } \\
\text { of Tests. }\end{array}$} & \multicolumn{2}{|c|}{ Positive Formol-Gel. } \\
\hline & & & & & Number. & Percentage. \\
\hline $\begin{array}{l}30-34 \\
35-39 \\
40-44 \\
45-49 \\
50-54 \\
55-59\end{array}$ & $\begin{array}{l}\ldots \\
\ldots \\
\ldots \\
\ldots \\
\ldots\end{array}$ & $\begin{array}{l}\ldots \\
\ldots \\
\ldots \\
\ldots \\
\ldots\end{array}$ & $\begin{array}{l}\ldots \\
\cdots \\
\cdots \\
\ldots\end{array}$ & $\begin{array}{r}6 \\
46 \\
135 \\
136 \\
93 \\
20\end{array}$ & $\begin{array}{r}6 \\
42 \\
50 \\
22 \\
2 \\
0\end{array}$ & 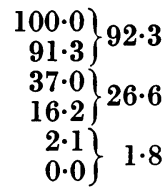 \\
\hline \multicolumn{2}{|c|}{ Total .. } & . & .. & 436 & 122 & \\
\hline
\end{tabular}

Table VIII.-To show the Effect of Delay on the ERythrocyte Sedimentation Rate, as indicated by the Difference in Readings taken within Three Hours and after Twelve Hours of THE Collection of Blood

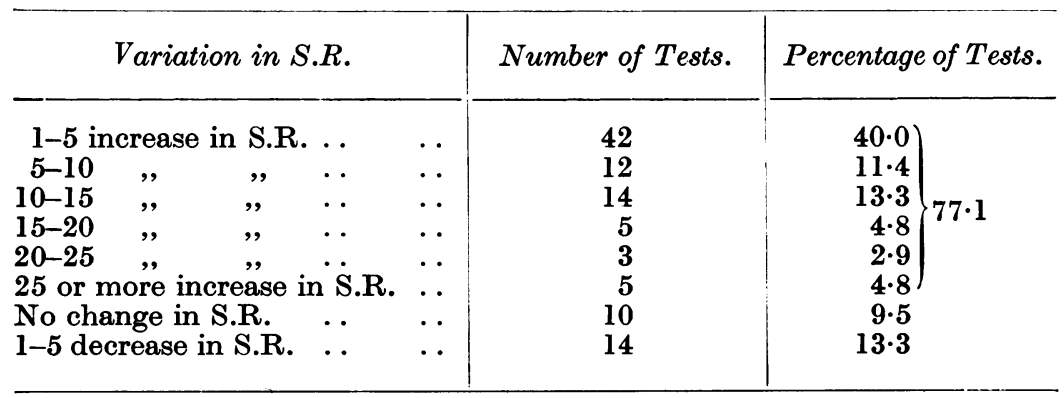

Table IX.-To show the Effect of Delay on the Formol-Gel Reaction, as indicated by the Difference in the Results of Tests made within Three Hours aNd after Twenty-Four Hours of the Collection of Blood

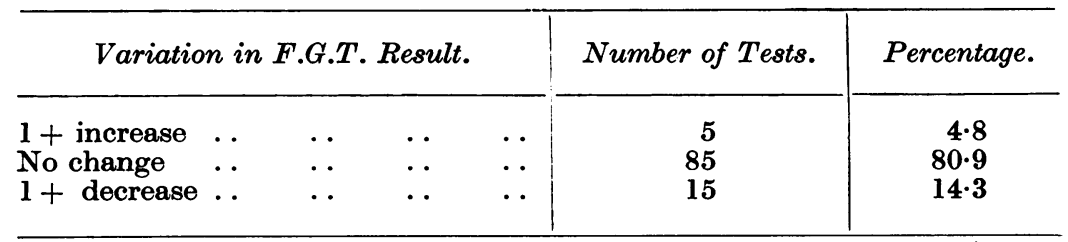


Table X.-To show comparatively the Results of Schultz and Rose and of Green in Regard to the Correlation of the Formol-Gel Reaction with the Erythrocyte Sedimentation Test in Rheumatism

\begin{tabular}{|c|c|c|c|c|c|c|c|}
\hline \multirow{2}{*}{\multicolumn{2}{|c|}{$\begin{array}{c}\text { Equivalent E.S.R. } \\
\text { Levels. }\end{array}$}} & \multirow{2}{*}{\multicolumn{2}{|c|}{$\begin{array}{l}\text { Number of Tests } \\
\text { at Each Level. }\end{array}$}} & \multicolumn{4}{|c|}{ Positive Formol-Gel. } \\
\hline & & & & \multicolumn{2}{|c|}{ Number. } & \multicolumn{2}{|c|}{ Percentage. } \\
\hline Schultz. & Green. & Schultz. & Green. & Schultz. & Green. & Schultz. & Green. \\
\hline $\begin{array}{c}100+ \\
70-99 \\
40-69 \\
20-39 \\
10-19 \\
0-9\end{array}$ & $\begin{array}{r}0-50 \\
51-65 \\
66-80 \\
81-90 \\
91-95 \\
96-100\end{array}$ & $\begin{array}{l}36 \\
24 \\
42 \\
63 \\
44 \\
66\end{array}$ & $\begin{array}{l}41 \\
61 \\
75 \\
95 \\
89 \\
66\end{array}$ & $\begin{array}{r}13 \\
16 \\
25 \\
23 \\
7 \\
2\end{array}$ & $\begin{array}{r}40 \\
53 \\
22 \\
5 \\
1 \\
0\end{array}$ & $\begin{array}{r}36 \cdot 1 \\
66 \cdot 6 \\
59 \cdot 2 \\
38 \cdot 7 \\
15 \cdot 9 \\
3 \cdot 0\end{array}$ & $\begin{array}{r}97 \cdot 6 \\
86 \cdot 9 \\
29 \cdot 3 \\
5 \cdot 3 \\
1 \cdot 1 \\
0 \cdot 0\end{array}$ \\
\hline
\end{tabular}

\section{REFERENCES}

Gaté and Pappacostas (1920): C. R. Soc. Biol., 83, 1432.

Gibson, H. J. (1938): Acta Rheumatologica, Nos. 36-37.

HolborRow, A. G. (1922): Lancet, ii. 274.

NAPIER, L. E. (1921-22): Ind. Journ. Med. Res., 9, 830.

NAPIER, L. E., aNd Henderson, J. M. (1931): Ibid., 19, 691.

Preffer, G. (1925): Klinische Wochenschrift, 4, 497.

Scholtz, M. P., aNd Rose, E. J. (1939): U.S. Pub. Health Rep., 54, 248. Spackman, W. C. (1921): Brit. Med. Journ., ii. 266.

ZeCKWER, I. T., AND GOODELL, H. (1925) : Amer. Journ. Med. Sci., 169, 290. 